\title{
The Double Entendre of Sex: Pornographies of Body and Society in Péter Esterházy's Fiction*
}

\section{Enikő Bollobás}

\begin{abstract}
Informed by feminist theory on the one hand and thematic and rhetorical criticism on the other, this article examines the components of discourse in two books by Péter Esterházy that share an emphatic attention to sexuality. The author interprets Esterházy's discourse of sex as grounded in the figure of the double entendre, with a different function in each work. In Kis magyar pornográfia ['A Little Hungarian Pornography'], vulgar corporeality and communist politics are shown as commensurate; both have a double meaning, with sex and politics referring both to themselves and to each other. In using one discourse as a cover for another, Esterházy continues the Central European Witz ['joke'] tradition, giving a particular twist to it by making the transference of meaning two-directional, thereby assigning double meanings to sex and politics alike. In Egy nö ['She Loves Me'], Esterházy attaches a double meaning to sex in a different manner; here sex is not a cover for something else but is shown to be reduced to itself, with a double meaning attached to its internal power relations. Sex is presented as a power game, in which man is repulsed by women yet is hopelessly attracted to them. Moreover, sex acts as the only tellable story taking the place of the untellable story of love. In this piece of postmodern fiction, the multiple perspectives bring about an interpretational uncertainty on the part of the reader as to whether sexist discourse is legitimized or subverted, and whether this legitimization and/or subversion is carried out by the narrator and/or by the implied author.
\end{abstract}

Keywords: Péter Esterházy, double entendre, literary pornography, sexual politics, patriarchy, communism, male gaze

Biography: Enikő Bollobás (D.Litt.), who is Professor of Literature at Eöt vös Loránd University, Budapest, has published extensively on American and Hungarian literature. Her books include monographs on the poets Charles Olson and Emily Dickinson, two histories of American literature, and two theoretical inquiries into performativity and subjectivity in literature, American and Hungarian alike. Her numerous essays have come out in international

\footnotetext{
* I would like to thank Judith Sollosy, the translator of Péter Esterházy into English, and Zoltán Abádi Nagy, professor of literature at Debrecen University, for reading earlier drafts of this study and suggesting valuable improvements. I am also grateful to Hungarian Cultural Studies editors, editor-in-chief Louise O. Vasvári, of Stony Brook University and New York University, and associate editor András Kiséry, of The City College of New York, for their perceptive readings and thoughtful comments.
}

(cc) BY
New articles in this journal are licensed under a Creative Commons Attribution 4.0 International License.

This journal is published by the University Library System of the University of Pittsburgh as part of its D-Scribe Digital Publishing Program and is cosponsored by the University of Pittsburgh Press 
Bollobás, Enikő. "The Double Entendre of Sex: Pornographies of Body and Society in Péter Esterházy’s Fiction.” Hungarian Cultural Studies. e-Journal of the American Hungarian Educators Association, Volume 12 (2019) DOI: 10.5195/ahea.2019.362

scholarly journals, among them, American Quarterly, Arcade, Emily Dickinson Journal, Hungarian Cultural Studies, Journal of Pragmatics, Language and Style, Modern Philology, Paideuma, and Word and Image. bollobas.eniko@btk.elte.hu

Vulgarity, filth, and ugliness are heavily foregrounded in Péter Esterházy's fiction, contributing to a pornographic representation of sexuality, reflecting a reinforced and exaggerated system of gender and sexual domination. Whenever bodies and acts are described, they seem to come with a double meaning, referring both to themselves and something else. Esterházy's depiction of sexuality is overwhelmingly pornographic, involving bodies that are repulsive and sexual acts that are exploitative; moreover, the language used is blatantly sexist, reflecting a patriarchal male perspective. Framed by the figure of the double entendre, this sexist-pornographic discourse is then coupled with a discourse on politics and sexual politics, with the depiction of power dynamics running through all.

Back in the 1990s Hungarian feminist critics were challenged to reflect upon Esterházy's at times one-dimensional gender discourse, or nem különösebben összetett maszkulin szólamok ['not particularly complex masculine registers']; Palkó 1996: 89) and the provocative narrative assignment of gender roles (a nemi szerepek tematizálásának pikantériája ['the piquancy of his thematization of gender roles']; Szirák 1998: 68). Indeed, there are certain of his works where women and the acts they engage in are overwhelmingly described as vulgar, filthy, and ugly. Fucks and cunts abound; boobs, hooters, loose vaginas loom large; female fatness and the overall meghatározhatatlan rettenet ['unspeakable dread'] (Esterházy 1995b: 81; Esterházy 1997: 85-86) of the female body weigh down the narrative. With the usual playfulness and wit that is Esterhazy's trademark, what women do is ridiculed as offensive and low, whether eating, drinking, having sex, or performing fellatio. Female bodily repulsiveness, moreover, is sometimes described from a classed perspective, with female grossness as an inherent feature of the proli ['prole,' 'white trash'], as the narrator of She Loves Me puts it, claiming that female obesity is as much the sign of the Hungarian lower classes as of the American (Esterházy 1995b: 79; Esterházy 1997: 84-85). Even in his final non-fiction work, his cancer diary, the author invents such feminine or feminine sounding diminutives for the pancreatic cancer that would ultimately kill him as Hasnyálka, Édes kisasszony, or Mirigyke ['Little Pancrie,' 'Sweet Lady,' 'Glandulie'; Esterházy 2016: 24, 30, 87], gendering the deadly enemy as feminine.

Emphasis on female grossness and lowness, like all attributes assigned to men and women, derive from the sexual political codes operative in discourse. I use the term "sexual politics" and its derivatives in the sense introduced by Kate Millett (1971:23, 24), where the term "politics" refers to "power-structured relationships, arrangements whereby one group of persons is controlled by another," and "sex is a status category with political implications." Sexual relations need to be understood, Millett (1971: 24-25) insists, along the lines of Max Weber, "as herrschaft, a relationship of dominance and subordinance." Sexual political codes can be located in the foregrounding of the assumptions that are taken for granted, or naturalized. Indeed, as Nóra Séllei (2007: 113, 119) points out in a different context, it is because the codes have become so "natural" that we hardly notice them; that is why the critic must unearth the hátborzongató elszólások ['uncanny slips of the tongue'], as she does, in the writings of a politician, a philosopher, two literary critics, and a journalist. Yet in Esterházy's case no such textual archeological digging is necessary, for instead of hiding the gendered codes, he emphatically foregrounds them, either in 
Bollobás, Enikő. "The Double Entendre of Sex: Pornographies of Body and Society in Péter Esterházy’s Fiction.” Hungarian Cultural Studies. e-Journal of the American Hungarian Educators Association, Volume 12 (2019) DOI: 10.5195/ahea.2019.362

total seriousness or in parody, which also reads as deadly serious. Here the critic must interpret this excessive foregrounding and identify the sexual political codes hidden in the parody parasitic on the discourse of sexism.

In what follows I will discuss the double meanings of pornography in two works by Esterházy. I claim that the narrative of A Little Hungarian Pornography is grounded in the figure of double entendre in that pornography always has two interpretations, referring to both sex and politics. Because sexual codes duplicate political codes, wherever one is mentioned, the other is evoked. This doubleness runs through the narrative: Esterházy seems always to mean, or "understand," both. Here double entendre has the function to elicit laughter by evoking the Central European Witz ['joke'] tradition. In She Loves Me, pornography as double entendre consists in referring to both female repulsiveness and male powerlessness, while it also acts as a discourse shared by all the permutational alternatives given by the unreliable narrator. In each case, pornography is used as encompassing those gendered cultural codes that inform the patriarchal or sexist social discourse of a particular sexual politics. Esterházy ridicules these deep-seated gendered codes by unearthing them from the deep structure of social discourse and making them visible. His display is excessive, with parody shuffling between the two meanings in which he demands pornography to be understood.

\section{A Little Hungarian Pornography: Hungarian Communism as Pornographic}

Kis magyar pornográfia ['A Little Hungarian Pornography'] (1984, Hungarian edition/ 1995, English) is the representative product of the 1980s, from the last decade of the era (1956-1989) marked by the figure of János Kádár, First Secretary of the ruling Hungarian Socialist Workers' Party, when Hungary was supposedly the "happiest barracks" in the communist camp. As one of those books that are, as Esterházy puts it, "irrevocably the prisoners of the time in which they were written" (Esterházy 1995a: v), A Little Hungarian Pornography abounds in specific linguistic markers that evoke the period of Hungarian communism spanning from 1948. ${ }^{1}$ The book foregrounds the anomalies of Hungarian Stalinism of the fifties, marked by then First Secretary Mátyás Rákosi. This was a topic that communist censorship opened in the eighties by allowing

\footnotetext{
${ }^{1}$ Linguistic markers clearly evoking communism include formulae of contemporary politicians ("with...the wiser than wise counsel of its honorable and highly qualified leaders," [tisztességesés rátermett vezetöi bö-ö-ölcs irányításával] (Esterházy 1995a: 4; Esterházy 1984: 10), official bureaucratic language ("he has a very responsible job," [felelös munkakörben dolgozik] (Esterházy 1995a: 6; Esterházy 1984: 12), and the much favored use of commonplace language panels ("the problem lies hidden someplace else," [valahol egészen máshol búvik meg a probléma] (Esterházy 1995a: 64; Esterházy 1984: 12). Other historical-linguistic markers comprise references to ÁVÓ officers (ávós [belonging to the communist secret police), the ÁVÓ headquarters located at 60 Andrássy Street, the Stalin Bridge, or policemen typically "morose, irritable and frustrated" [rosszkedvü, mogorva, túlspannolt, frusztrált] (Esterházy 1995a: 3; Esterházy 1984: 8). References to workers’ hostels [munkásszálló], the League of Young Communists ['KISZ'], trade-union hostels [SZOT-üdülö], farmers' coops [téesziroda], "window" in the passport [ablak] (allowing its holder a single exit from the country), workers' brigades [munkásbrigád], and state-operated package tours [IBUSZ-út] clearly evoke the sixties and seventies in Hungary, together with mentions of Trabants and Pobyedas, restaurants with linoleum-tile floors, iconic undershirts [atlétatrikó], and fur panties [bundabugyi].
} 
Bollobás, Enikő. "The Double Entendre of Sex: Pornographies of Body and Society in Péter Esterházy’s Fiction.” Hungarian Cultural Studies. e-Journal of the American Hungarian Educators Association, Volume 12 (2019) DOI: 10.5195/ahea.2019.362

writers to criticize Kádár's predecessor as despotic and autocratic in order to emphasize Kádár's "socialism with a human face," as it was called at the time. What communist leadership did not foresee, however, was that by ridiculing the past (the Rákosi regime), some authors would also ridicule the present (the Kádár regime). This is exactly what Esterházy accomplished by using the trope of the double entendre: via a transfer of meaning, he would have his readers laugh at the absurdities of both the Rákosi era and "the overripe period of the Kádár era," as he puts it, both exhibiting blatantly "pornographic circumstances” (Esterházy 1995a: v).

A Little Hungarian Pornography is a loose compendium of anecdotes from the decades of fifties totalitarian communism. Interspersed with the more public anecdotes are the personal stories with implied male (and less frequently female) narrators, who record what they see. Other than the shared historical period, no unifying frame holds together the individual sections: the work has no linear plot with recurring characters engaged in the narrated events. Esterházy grounds his narrative in the Central European genre called Witz in German ['joke,' or vicc in Hungarian], a short funny story with a conspicuous double meaning. Usually told by the little man, the Witz is intimately tied to Jewish humor, having flourished at times when this little man suffering from political oppression, who was discriminated against, or simply could not say what he wanted to say. In Central Europe, the cabaret with its stand-up comedians served as the public stage of the Witz. Yet it was a private genre as well, told cautiously among friends, since its requisite double meaning provided outlets of comic relief during dictatorships, Nazi and Communist alike. Esterházy evokes the Witz tradition by always saying one thing and meaning another. Yet he also revises this tradition by consistently employing the figure of the double entendre, creating a double Witz of sorts, where the two components each have double meanings. To translate the French term literally, the figure of the double entendre not only allows a word or phrase to be "understood" in its "doubleness," in a tone that is both humorous and serious, but also exhibits the specificity of reciprocal duplicity. The double entendre differs from the Witz in being informed by a sense of "bothness," so to speak, where the author means both what is said and what is implied. As such, the double entendre bears a family resemblance to parody which, as Keith Oatley (2011: 48) claims, is a "mode of play in which something is both itself and something else." It is exactly this double meaning and double tone, as well as the bothness of meaning something and something else, that Esterházy's text exploits, making it possible that we laugh both at the stories of sex as cover stories for politics and at the stories of politics as cover stories for sex.

In several instances of the double entendre, sexual and political references are so thoroughly intertwined that it is impossible to separate them. One passage, for example, presents the policeman kissing his rubber stick. "Once upon a time there lived a cop, and once this cop, for reasons that must remain obscure, kissed his stick" [Élt egyszer egy rendör. Ez a rendör egyszer, volt rá oka, megcsókolta a gumibotját] (Esterházy 1995a: 2; Esterházy 1984: 8). In the decades of communist totalitarianism, the police was the most visible, therefore most hated, $\operatorname{cog}$ in the machinery of state oppression, the arm put in the service of total power. Although Hungarian police was armed with guns too, the policeman's baton was the most common tool of everyday police brutality, always at hand to intimidate or, for that matter, to beat up citizens, often with no particular reason. In this context, the policeman who kisses his "stick" expresses his delight in his oppressive power; at the same time, given the phallic associations of the stick, the policeman also swells with pride in his sexual power, which seems inseparable from political power, and as such can also be used as a means of oppression. In several anecdotes of A Little Hungarian Pornography, communist functionaries demand sexual pleasures from those they dominate politically. The "officer" on the 
Bollobás, Enikő. "The Double Entendre of Sex: Pornographies of Body and Society in Péter Esterházy’s Fiction.” Hungarian Cultural Studies. e-Journal of the American Hungarian Educators Association, Volume 12 (2019) DOI: 10.5195/ahea.2019.362

train enters into casual sex with a stranger, expecting the woman to oblige without hesitation. However, of course it is not the person she cannot resist but rather the "officer" behind the man, who can be either a military, police, or secret police officer, a representative of political oppression in either case. Moreover, she is quite impressed by his decorations, noticing that his medals sounded at his every move: "The decorations on his chest jingled every time he [self-censored]," $[A$ kitüntetések összecsördültek, valahányszor [öncenzúra]] (Esterházy 1995a: 15; Esterházy 1984: 22).

In some cases, political references are to be understood as also having sexual connotations. The vocabulary of Marxism is expanded to apply to sex in the part where the Hungarian-born opera singer with a career in foreign opera houses makes a pass at First Secretary Rákosi; here the woman is described as "the little Hungarian working girl with the international experience" [A kis magyar munkáslány internacionalista tapasztalattal] (Esterházy 1995a: 53; Esterházy 1984: 63), giving Marxist "internationalism" a double entendre of sexual experience with foreigners. Most often, the actors of sexual encounters are party members, party functionaries, and party leaders, who repeat well-known party slogans with double meanings, such as a demokrácia fejlesztése ['the advanced state of democracy'] (Esterházy 1984: 36; Esterházy 1995a: 28), társadalmi kielégülés ['social satisfaction'] (Esterházy 1984: 37; Esterházy 1995a: 28] and az ilyen heves átalakulások járhatnak fájdalommal ['such vehement transformations can be accompanied by pain'] (Esterházy 1984: 37; Esterházy 1995a: 29), in which the political catchline always has sexual connotations (here referring to the progress of a sexual relationship, sexual satisfaction, and the pain of sex). In other instances, sex serves as the currency of social commerce. This happens, for example, on the "luxury" boat used on the Danube and Lake Balaton, carrying three naked girls who have been taken advantage by their bosses with the promise of a pay raise (Esterházy 1995a: 18-20; Esterházy 1984: 27-28). The dominant themes running through such relationships, the narrator claims, are politics combined with sex, or szociális érzékenység plusz petting ['social responsibility plus petting'] (Esterházy 1984: 32; Esterházy 1995a: 24).

Sexuality understood as both sexuality and politics provides the overwhelming majority of Esterházy's double entendre in A Little Hungarian Pornography. This presentation of sexuality is unashamedly sexist, suggesting that sexual relations in a totalitarian regime are as controlling, oppressive, and dehumanizing as political ones. The codes that make up this sexist discourse include such topoi as female ugliness, the female body, especially breasts, buttocks, and genitals, as well as repulsive sex. Woman is overwhelmingly presented in negative terms, as ugly and deficient, as the following examples testify: "The lady is not only unsightly but repulsive?" [A lady nemcsak randa, de gusztustalan is?]; (Esterházy 1995a: 146; Esterházy 1984: 171); “the girl's hair being sour and foul-smelling, a sticky, stiff ringlet flaps against your cheek" [a lány haja savanyúan büdös, egy ragadós, kemény tincs birizgálja az arcát] (Esterházy 1995a: 147; Esterházy 1984: 172). The implied narrator is constantly preoccupied with the female body, picking out the woman with the big nose (Esterházy 1995a: 178; Esterházy 1984: 206) and the one who is sápatag, vékony lány ['pale and skinny'] (Esterházy 1984: 229; Esterházy 1995a: 198). He seems obsessed with female breasts, elevating them into the primary distinguishing feature of the person who sits behind her teli csöcsöcskéi ['behind her two hooters'] (Esterházy 1984: 21; Esterházy 1995a: 14), calling the woman simply a mellek gazdija ['the owner of the boobs'] (Esterházy 1984: 31; Esterházy 1995a: 23). Unable to get over the fact that she has inordinately huge breasts ("I'd never seen boobs so huge before," [Életemben ekkora melleket nem láttam] (Esterházy 1995a: 23; Esterházy 1984: 31), the narrator describes the breasts as overwhelming, approaching "boosiasm" ("each of these was a 
Bollobás, Enikő. "The Double Entendre of Sex: Pornographies of Body and Society in Péter Esterházy’s Fiction.” Hungarian Cultural Studies. e-Journal of the American Hungarian Educators Association, Volume 12 (2019) DOI: 10.5195/ahea.2019.362

real live boosiasm to boost your enthusiasm," [valódi izgö-mozgó csöcs volt], (Esterházy 1995a: 23; Esterházy 1984: 31).

Esterházy presents sexual pornography from a male sexist perspective, from the position of the male pornographic gaze. The narrative captures the women in humiliating positions, recording the narrator's infatuation with both breasts and buttocks: "When Ilon stands over me on all fours the domes of her breasts hang down, down, she wiggles her rear end vigorously, her boobs dangle" [Ha Ilon négykézláb áll fölöttem, a melle kupolái lógnak le, lefelé; erösen rázza a farát, a mellek lengenek] (Esterházy 1995a: 62; Esterházy 1984: 72).

The narrator's fixation on the female genitals offers a similar source of twisted humor. For example, we read about the dutiful wife who accepts the husband's complaint that her vagina is too loose that "it feels like a musician playing in a concert hall too big for his purposes," [Azt mondja az uram, bö...úgy tetszett, mint egy muzsikus, aki túl nagy koncertteremben játszik; (Esterházy 1995a: 7; Esterházy 1984: 13) and for this reason puts up with his affairs, willing to sleep with the kids while in their bedroom the husband has sex with the other woman. In order to boost the husband's pleasure, she also complies with his wish to do pelvic exercises to tighten her vaginal muscles, "for a woman's cooch, like a fortification by soldiers or a honeycomb by bees, is circled all around by muscles," [merthogy a nö picirije, akár egy vár katonákkal vagy a lépes méz méhekkel, izmokkal van körülvéve] (Esterházy 1995a: 7-8; Esterházy 1984: 14). Compared to the recurring recitations of female ugliness, especially where the female genitals are concerned, male genitals are paid far less - and certainly more respectful — attention in this work. In one place, a man, Gyurka Nagy, having a huge penis is described as "the proud owner of a huge $\sim$; we men slapped him on the back as if he had done well by us.... Enmeshed by a wild growth of thick, swelling veins like so many mistletoes that held it in thrall, it was strong and wide like a haycock's" [Gyurkának hatalmas vesszeje volt - férfiak viharosan veregettük a vállát, mintha, úgymond, kitett volna értünk ...erös és széles, mint egy petrencerúd, a kék, vastagon dundorodó erek vadul körbefonták, akárha fagyöngy, szinte szorították] (Esterházy 1995a: 63; Esterházy 1984: 74-75). Labels and synonyms are tactfully avoided, in fact substituted for by the swung dash or tilde, as if out of shyness or bourgeois decency. ${ }^{2}$ Only a basic classification is offered, differentiating between "the wiener" and "the whamdanger” (Esterházy 1995a: 63) [vér és hús ; Esterházy 1984: 75].

Discrepancies between depictions of the female and the male body are telling elements of the gendered code: woman is predominantly the object of the narrator's gaze, while he, the male narrator, takes the subject position, only rarely objectivizing the male body (the case of Gyurka Nagy being an exception). The narrator routinely sizes up women, subscribing to the traditional codes of gendered representation in the sense Susan Bordo (1999: 173) defines the basic formula of this attitude, to the effect that "men are not supposed to enjoy being surveyed, period. It's feminine to be on display." A wealth of descriptions relate to female corporeality, while male looks get disproportionately scanter narrative attention, and when they do, this attention is considerably friendlier. The few times when the male body is surveyed, its positive features are emphasized. The same features receive different interpretations: while with regard to men "bigness" is a positive feature, with regard to women, huge breasts and loose vaginas contribute to the woman's ugliness.

\footnotetext{
${ }^{2}$ As seen from the cited passage, the American translator inserted the tilde in another sentence than the author did in the Hungarian original; this is an accepted technique of translation, called stylistic compensation.
} 
Bollobás, Enikő. "The Double Entendre of Sex: Pornographies of Body and Society in Péter Esterházy’s Fiction.” Hungarian Cultural Studies. e-Journal of the American Hungarian Educators Association, Volume 12 (2019) DOI: 10.5195/ahea.2019.362

Gender discrepancies do not make it easy for women readers to laugh through A Little Hungarian Pornography. Esterházy's female readers are often "resisting readers," to apply Judith Fetterley's by now classic term, in the sense that they have difficulties identifying with the male perspective. In (American) literature, Fetterley (1978: xii) observes, "the female reader is co-opted into participation in an experience from which she is explicitly excluded...she is required to identify against herself." The American critic's words seem to hold true for the reader of Esterházy's prose as well, in particular, for A Little Hungarian Pornography: while appreciating the humor and the irony, the woman reader has to identify with either the male subject position of the narrator or the female object position of women portrayed - not to mention the filth, ugliness, and vulgarity marked as part and parcel of female existence. Although the double entendre of female vulgarity and abusive sex evokes vulgar politics and abusive political exploitation, we must remember that like metaphors, double meanings also hide presuppositions, preconceptions, and bias. As such, they are not, as Séllei (2007: 123) emphasizes, "innocent.” Indeed, it is always women whom Esterházy presents as ugly and repulsive, and it is always female sexuality that is depicted as pornographic. It is therefore no wonder that although women readers may also laugh at Esterházy's irony and humor, they laugh with a certain resistance, fully aware of the fact that humor operates at their expense.

The double entendre mode should not be understood as establishing one-to-one correspondences. I am not suggesting, for example, that a direct equivalence should be set up between the woman's willingness to tighten her loose vagina and, let's say, a possible willingness to comply with any desire of the oppressor, for such direct correspondences would only offer a simplistic interpretation of double entendre humor. Esterházy devises a more complex method when constructing a discourse detailing the features of what he terms pornography: among them, degradation, exploitation, abuse, humiliation, corruption. He then assigns these features to both political and social conditions, bringing them together in the figure of the double entendre. Humor derives from the often surprising coupling of these conditions via the common feature of pornography, where the reader is expected to laugh simultaneously at both repulsive sex and communist politics.

\section{She Loves Me: Permutations of Male and Female Vulnerability}

Egy nö ['She Loves Me,' 1995, Hungarian/1997, English] is a first-person account of ninetyseven individuals - or one individual in ninety-seven incarnations - who love and/or hate the male narrator, and who have (are having) sex with him. This text made up of ninety-seven short sketches has an unreliable narrator grounding it in unresolvable ambiguities. For this reason, I offer three different readings, of which two are thematic and one rhetorical. The thematic readings touch upon the double thematics of sex, while the rhetorical reading unpacks the structural double entendre of the text.

Assuming that a fictional text can act like a sentence with its own topic-comment structure, my first thematic reading posits that woman is the topic, while the features applied to her description and the stories related constitute the comment part of the narrative. The short sketches are given by one anonymous male narrator in the position of the speaking subject, while woman as a generic entity is put in the object position in the accounts about the male narrator engaging in impersonal sex with female partners whom he leaves anonymous. The narrator feels no empathy for women; he uses them as sex objects for his own satisfaction. The parody is based on excessive repetition, each revealing the hidden cultural codes and emphasizing that, blinded by his misogyny, 
Bollobás, Enikő. "The Double Entendre of Sex: Pornographies of Body and Society in Péter Esterházy’s Fiction.” Hungarian Cultural Studies. e-Journal of the American Hungarian Educators Association, Volume 12 (2019) DOI: 10.5195/ahea.2019.362

the narrator sees women as embodying a wealth of corporeal pathologies. His partners are put on display as objects of the male narrator's gaze, where they are seen as beautiful and ugly, young and old, active and passive, assertive and submissive, bitchy and docile, but mostly easy, loose, or as Bram Dijkstra (1986: 5) calls such women "idols of perversity," "not-so-ideal women." What these negatively described women share, however is that they all described as loving and/or hating the narrator, while the latter rarely mentions that he himself loves particular women. When he does do so, he doesn't fail to add how that particular woman nevertheless bores him: "I love her. Right now I'm sick of her body...I'd rather beat my meat" (Esterházy 1997: 151) [Szeretem. Momentán unom a testét.... Kiverem a farkam inkább] (Esterházy 1997: 151; Esterházy 1995b: 137).

The narrator classifies his female partners according to how he judges the quality of the intercourse he has had with each. For example, \#9 is "a great lay. Fucks like an angel” (Esterházy 1997: 19) [Jól szeretkezik. Magyarán istenien baszik] (Esterházy 1997: 19; Esterházy 1995b: 21), while sex with \#8 is described as személytelen élvezet ['impersonal carnality'] (Esterházy 1995b: 19-20; Esterházy 1997: 18). The narrator forced woman \#11 to give him a blow job: "I forced her to take me in her mouth" [kényszerítettem, hogy vegyen a szájába] (Esterházy 1997: 24; Esterházy 1995b: 25); \#14 seduces him wherever she sees him; at such times her desire is overwhelming: "She can't live without me. She needs me. I must help" (Esterházy 1997: 34) [Nem bírja nélkülem. Szüksége van rám, segítsek] (Esterházy 1997: 34; Esterházy 1995b: 34). Most women are passionate with the narrator, which he recounts with pride. For example, \#4 is infatuated by his name, while \#96 is attracted to his penis, unable to control herself in its presence. Other women are described as learned and intelligent in their peculiar ways (\#5, \#7); some exhibit gender ambiguity (\#50), while another is actually a man who takes the place of the woman (\#93). The single section in which a man is put in the position of the women is the odd one out in the sense that here the partner is not described the usual way as an object or spectacle - with a focus on the body, especially the genitals, and the way of love-making - but as a subject with a voice. \#93 is, in fact, the only person who the narrator quotes, citing over two pages from his letter about the deep love he feels for the narrator. In other words, the only person who is a speaking subject in this exhibition of women is a man.

Throughout, She Loves Me constructs a discourse of subjection of the female to male desire by repeatedly showcasing the female body as the vulgar object of the gaze. It is the male gaze that seems to turn female corporeality into spectacles of ugliness and repugnance, whether of foul mouth odor, loathsome texture of the flesh, gruesome big feet, hairy armpits, dreadful face behind the glasses, or overall obesity. Especially the female genitals fill the voyeuristic spectator with disgust: "A horrible spectacle, a howling crater, like an explosion. You'd think a tiger had mauled it. You could almost see the parallel destruction of its lethal claws" [Iszonyatos látvány...vad kráter, akár egy robbanás. Mintha tigris marcangolta volna szét. Az ember látni vélte a karmok párhuzamos pusztítását] (Esterházy 1997: 91; Esterházy 1995b: 87).

The narrator also expresses an ultimate horror over female fatness, which he considers a definitive part of woman's ugliness (\#39). Not only does he describe female obesity as ugly and repulsive, but also as lower class. By presenting fatness as the vulgarity of the proli ['prole'], he performs a classist gesture, linking Hungarian female obesity, moreover, to the image of American lower class women: "She's as fat as an American, an American proli in Disneyland, only they can be this fat, like a house, like a hippopotamus.... Even her hair is fat, heavy, cascading, maddening, impossible to curb, to restrain," [Olyan hájas, mint egy amerikai, egy amerikai proli Disneylandben, 
Bollobás, Enikő. "The Double Entendre of Sex: Pornographies of Body and Society in Péter Esterházy’s Fiction.” Hungarian Cultural Studies. e-Journal of the American Hungarian Educators Association, Volume 12 (2019) DOI: 10.5195/ahea.2019.362

azok birnak ilyen hájasak lenni, szekrények, vízilovak... A haja is kövér, nehéz, zuhogó, örjöngö, lehetetlen befogni, gátat szabni neki] (Esterházy 1997: 84-85; Esterházy 1995b: 79).

Throughout She Loves $M e$, the female body is excessively foregrounded, while the male body is mentioned only a couple of times. Moreover, the ugly, the repulsive, and the horrendous are equated exclusively with the female body, while positive terms are assigned to the male body only. In this respect the narrator seems to endorse fully the dominant cultural paradigm regarding the gendered body as described by Peter Lehman (1993: 3-4), who claims that the "near-total attention to the woman's body" characterizing film, literature, art, and photography, together with "the silence surrounding the sexual representation of the male body" is "totally in the service of traditional patriarchy." Indeed, the narrator indulges in what Kate Millet (1971) referred to as "the mystery of the phallus," as when he regards himself with adulation, taking pleasure in his "prick power" and seeing himself as approximating corporeal perfection ("uncover my genitals, what I mean is, my prick, hey-ho, tally-ho! here I am!" [fölfedem a szeméremtestem, abból is a faszomat, itt vagyok! hahó!] (Esterházy 1997: 40; Esterházy 1995b: 39), and sees himself (“a personable, slender youth" [Elegáns, karcsú fiatalember Esterházy 1997: 91; Esterházy 1995b: 87]). For the narrator, woman is just cunt, and sex is like tackling a slot machine, where the coin of the perfect male body will trigger female pleasure: "my body being the coin thrown into her to make her click" [félkarú óriás vagyok az ágyban] (Esterházy 1997: 20; Esterházy 1995b: 22). In this compulsive repetition of the sex narrative, we encounter what Millett $(1971: 312,313)$ describes as "the cheap dream of endlessly fucking impersonal matter, mindless tissue endlessly compliant," accompanied by "the thrills of egotism." The masculine hostility permeating the sketches makes the text overly misogynist. In this regard, She Loves Me presents pornographic sex in a more extreme, more pronounced manner than A Little Hungarian Pornography did; while in the book discussed earlier, pornography was put in the service of telling the story of politics, in the latter's first thematic reading, pornography refers simply to itself. As I discuss in the second thematic reading and the rhetorical reading below, sex receives its double meaning when it is shown to be a power game with reversible roles as well as when it is presented as a cover story for something that is untellable in the postmodern mode.

My second thematic reading takes its departure from the assumption that excess provides the grounds for parody in literature. In She Loves Me excess-based parody is clearly indicated by the inordinate repetition of female corporeal ugliness, captured in comparably excessive misogynist language. Parody is also suggested by the light-hearted, playful, mocking, scoffing Esterházy tone, which ridicules the patriarchal ideology embedded in the sexist discourse (on parody subverting ideology, see Slethaug 1993: 604). By the reversal of perspective, parody inspects that man, reversing thereby the subject-object relations. Esterházy's playful double entendre reverses the gaze in the Lacanian manner, and the woman who was formerly the object of the gaze now becomes its subject (on the Lacanian reversal of the gaze, see Dragon 2011: 26); it is her turn now to gaze at the man who, while dreading the female body, is willessly drawn to it. The patriarchal man who believes he dominates woman, is overpowered by her, unable to resist female power. This reversal goes hand in hand with the reversal of topic-comment relations, positing man as the topic of the narrative, with accounts of women functioning as comment. Following this reversal, the litany of sex with ninety-plus partners now shows women in the grammatical subject positions. Indeed, each section begins with woman as the grammatical subject: "There's this woman. She loves me" [Van egy nö. Szeret] or "There's this woman. She hates me" [Van egy nö. Gyülöl]. Also, in terms of 
Bollobás, Enikő. "The Double Entendre of Sex: Pornographies of Body and Society in Péter Esterházy’s Fiction.” Hungarian Cultural Studies. e-Journal of the American Hungarian Educators Association, Volume 12 (2019) DOI: 10.5195/ahea.2019.362

action, women are placed in the agent position for having the sole opportunity to satisfy the uncontrollable desire of men now in the patient position.

Although, as my first thematic reading suggests, the book seems to put women - as well as female corporeality, ugliness, vulgarity - as objects in the center of narrative attention, the double entendre achieved by the reversal of topic-comment relations transfers thematic centrality as the object of narrative attention to the male narrator. Indeed, it is he who functions as the dramatic blindspot, in the sense Réka Cristian (2005: 88) introduces this term, as "the link that establishes the reason and meaning for all the other events" or as "a character...that represents the visible part of the unsaid, the repressed, the unheimlich, the unfamiliar, strange figure who is the most important key to the understanding of the plot" (Cristian 2006). For in spite of what the Hungarian title (Egy nö [literal translation: 'one woman']) suggests - that the book is about women - it is the desire of man that holds together all the narratives. When reversed by what I called structural double entendre, man becomes the object of the gaze, much like Vera Benczik (2013) describes the reversal of the gaze in the James Bond movie Casino Royale, where the physically hurt Bond reveals, as object of the gaze, his broken body, thereby signaling a most un-Bond-like vulnerability. By the same token, by reversing the gaze, as well as textual topic and comment relations, Esterházy foregrounds the helplessness of the broken man, whose sexual drive will stop at nothing, whose physical desire cannot be controlled. Male disempowerment becomes as important a theme in the novel as is female corporeality, for the desiring man is at the mercy of woman, no matter what.

The double entendre reversal of one thematic reading into the other indicates that while the many faces of female corporeality are ridiculed by the male chauvinist narrator, the self-image of male virility is also parodied. Moreover, while both the object and the subject of sexist egotism are displayed on this parodic stage, the patriarchal man's perception of female corporeality and man's powerlessness at the female body are both asserted and questioned. Yet even if we are willing to accept that double entendre turns sexist discourse into a parody of male sexual conduct, it is very difficult to fully exempt Esterházy of charges of patriarchal sexual politics, since by employing double entendre, the figure of "bothness," utter uncertainty prevails as to what the reader should laugh at. Indeed, this parodic double entendre is first and foremost undecidable because, to apply Linda Hutcheon's (1989: 97, 101, 106) acute observation, parody is always “doubly coded...it both legitimizes and subverts that which it parodies," "inscribing as well as undermining it" in a complicitous way. To be sure, by creating a narrator who is both repulsed by the female body and hopelessly drawn to it, and by employing the double entendre figure to destabilize authorial intention, Esterházy seems also to legitimize as well as subvert pornographic discourse. As the author performs the gesture of double entendre, the narrator assumes total unreliability as to whether (or when) female corporeality and male vulnerability are embraced or ridiculed.

Ultimately, She Loves Me's postmodernity is most prevalent in its approximating what, in his seminal study on postmodern fiction, Zoltán Abádi Nagy takes as representative narrative techniques of the postmodern text: bonyolult játékosság ['complex playfulness'] (1987: 26), a képtelenségekben való tobzódás (1987: 26) ['excessive abundance of impossibilities'], and permutational fiction with alternatív narratív vonalak ugyanabban a szövegben (1987: 29) ['holding alternative narrative lines in the same text']. Indeed, Esterházy seems to allow his narrator to travel through alternative narrative lines by recounting all possibilities of sexual intercourse, playfully evoking all contrary and even contradictory plot lines - to the degree that their holding together within one narrative becomes utterly impossible. Through the ninety-plus versions of the 
Bollobás, Enikő. "The Double Entendre of Sex: Pornographies of Body and Society in Péter Esterházy’s Fiction.” Hungarian Cultural Studies. e-Journal of the American Hungarian Educators Association, Volume 12 (2019) DOI: 10.5195/ahea.2019.362

sex story, not only do we learn about the different ways of looking at sex, the open possibilities of the sexual adventure, but also about the ways man relates to sexuality.

Viewed from the rhetorical perspective, pornography in She Loves Me informs both language and narrative. As language, pornography locks all players into its patriarchal-sexist grid, obstructing meaning and meaningful communication. Language is not a transparent glass allowing the speaker to see or speak through, nor does it point to anything outside itself. Locked into language and determined by language relations, agency and patiency are assigned to those who occupy corresponding grammatical (subject or object) positions. In other words, what characters do in this piece of fiction is solely determined by the rhetoric of the narrative. That is, when women are presented as the objects of the discursive gaze (with their full corporeality presented), they become patients; when women are put in the grammatical subject position ("She loves/hates me"), women are assigned agency, while men become patients at the mercy of women. Pornography is not a theme with an actual outside reference, nor is it a metaphor for something larger, but frames instead a reductionist language game, prohibiting words to produce meaning. Out of a tautological identification of topic and comment, all that can be affirmed is that pornography is the language of pornography. Put simply, pornography is pornography.

As narrative, the pornographic excludes all other narratives. Stories of gendered corporeality are repeated excessively, with an endless parodic retelling that excludes all possibility of telling any other story. Only the impossibility of telling can be told, and only the narrative failure can be repeated again and again. Plot and fixed set of characters are substituted by the obsessive repetition and further permutation of the only possible story, the sex story. To apply Pál Hegyi's $(2019: 9,52)$ succinct claim formulated in connection with the weird in detective fiction, this narrative also "generates self-referential texts about the impossibility of reading" — and, one must add, of telling. Esterházy's text also reveals a certain uncanniness in the sense that the ninety-seven sections together offer a "tale never-to-be-told," thereby "creating an atmosphere of utter uncertainty." Therefore, what Hegyi claims elsewhere (1998: 83) can be adopted again, as "narratability is thematized, while the telling of the story itself becomes the story" (a történet elmondódását tematizálja, s a történet elmondása maga is történetté válik). Since telling the story is impossible, the writer can only tell about untellability, whose compulsive repetition gets thematized, the obsessive retelling of one story telling the story of untellability. In the grand scheme of the narrative, another double entendre is at work, or more precisely, is shown to not work: only the sex story is told repeatedly, while its other "understanding" remains untellable. This is probably the story of love, passion, loyalty, and intimacy.

\section{Conclusion}

In the two books discussed above, Esterházy foregrounds pornography, sex, and carnality with wry humor. The double entendre in A Little Hungarian Pornography allows sexual conditions to evoke political conditions, and political conditions to evoke sexual conditions, both informed by such explicitly pornographic features as exploitation, abuse, humiliation, and moral corruption. In She Loves $M e$, pornography serves as the thematics carrying both woman's and man's participation in sex as a game of power. Rhetorically, all stories are reduced to the one possible story, that of pornography, told in permutational alternatives.

The thematics shared by all the supposedly pornographic states consists in the difficulty of meaningful human relations. The body may often be vulgar, filthy, and repulsive, yet it is still, as Elizabeth Grosz (1994: 86) puts it, the only "phenomenon experienced by me and thus provides the 
Bollobás, Enikő. "The Double Entendre of Sex: Pornographies of Body and Society in Péter Esterházy’s Fiction.” Hungarian Cultural Studies. e-Journal of the American Hungarian Educators Association, Volume 12 (2019) DOI: 10.5195/ahea.2019.362

very horizon \& perspectival point which places me in the world and makes relations between me, other objects, and other subjects possible." To give a possible interpretation to the example I left unreflected at the beginning of my article, even pancreatic cancer can be tamed when the person relates to it as subject, giving it feminine diminutives as Hasnyálka, Édes kisasszony, or Mirigyke ['Little Pancrie,' 'Sweet Lady,' 'Glandulie'] (Esterházy 2016: 24, 30, 87), thereby embracing not only the illness but, through it, death.

The two books discussed here suggest that rarely do intersubjective relations come about, but when they do, they come about via the body. Means of intersubjectivity, a Maurice MerleauPontyan Esterházy seems to claim, include the valorization of the body, the construction of a corporeal interworld, and the recognition of the other as subject (see Merleau-Ponty 1992). Here lies the ultimate irony of sex and bodily existence: no matter how vulgar, pitiful, and ugly the body might be at times, only by accepting the primacy of the body is humankind capable of overshadowing, and only momentarily, its relentless solipsism. Or, as the untellable story might go, only love is the antidote to death.

\section{Works Cited}

Abádi Nagy, Zoltán. 1987. “A posztmodern regény Amerikában” ['Postmodern Fiction in America']. Helikon XXXIII/1-3: 7-42.

Benczik, Vera. 2013. "Átjárások: önreflexivitás és a megtört test ikonográfiája a Skyfallban” ['Intersections: Self-Reflexivity and the Iconography of the Broken Body in Skyfall']. Apertúra IX/1. http://uj.apertura.hu/2013/osz/benczik-atjarasok-onreflexivitas-es-a-megtort-testikonografiaja-a-skyfallban/

Bordo, Susan. 1999. The Male Body: A New Look at Men in Public and in Private. New York: Farrar, Straus and Giroux.

Cristian, Réka M. 2005. “The Ambiguous Male of Tennessee Williams's Subversive Textual Strategies." The 1950s: Proceedings of the 2003 Biennial Conference of the Hungarian Association of American Studies. Ed. Enikö Bollobás and Szilvia Nagy. Budapest: Eötvös Loránd U: 87-101.

Cristian, Réka M. 2006. "From Delicate Absence to Presence. The Child in Edward Albee's Alternating Families." AMERICANA e-Journal of American Studies in Hungary 2/2. http://americanaejournal.hu/vol2no2/cristian-essay

Dijkstra, Bram. 1986. Idols of Perversity. Fantasies of Feminine Evil in Fin-de-Siècle Culture. Oxford: Oxford UP.

Dragon, Zoltán. 2011. Tennessee Williams Hollywoodba megy, avagy a dráma és film dialógusa ['Tennessee Williams Goes to Hollywood, Or the Dialogue of Drama With Film']. Szeged: Americana eBooks. http://ebooks.americanaejournal.hu/books/tennessee-williamshollywoodba-megy/

Esterházy, Péter. 1984. Kis Magyar pornográfia ['A Little Hungarian Pornography’]. Budapest: Magvető Kiadó.

--------. 1995a. A Little Hungarian Pornography. Trans. Judith Sollosy. Evanston: Northwestern UP.

-------. 1995b. Egy nő ['One Woman’]. Budapest: Magvető Kiadó.Esterházy, Péter. 1997. She Loves Me. Trans. Judith Sollosy. London: Quartet Books. 
Bollobás, Enikő. "The Double Entendre of Sex: Pornographies of Body and Society in Péter Esterházy’s Fiction." Hungarian Cultural Studies. e-Journal of the American Hungarian Educators Association, Volume 12 (2019) DOI: 10.5195/ahea.2019.362

Fetterley, Judith. 1978. The Resisting Reader: A Feminist Approach to American Fiction. Bloomington: Indiana UP.

Grosz, Elizabeth. 1994. Volatile Bodies. Toward a Corporeal Feminism. Bloomington: Indiana UP. Hegyi, Pál. 1998. “Az olvasás rettenete” ['The Horror of Reading']. Tiszatáj 52/11: 83-90. ----. 2019. Lovecraft Laughing: Uncanny Memes in the Weird. Szeged: Americana eBooks. Hutcheon, Linda. 1989. The Politics of Postmodernism. London: Routledge.

Lehman, Peter. 1193. Running Scared. Masculinity and the Representations of the Male Body. Philadelphia: Temple UP.

Merleau-Ponty, Maurice. 1992. Phenomenology of Perception. Trans. Colin Smith. London: Routledge.

Millett, Kate. 1971. Sexual Politics. New York: Avon Books.

Oatley, Keith. 2011. Such Stuff as Dreams: The Psychology of Fiction. Malden: Wiley-Blackwell.

Palkó, Gábor. 1996. "A meztelen magyar férfi (nö)" ['The Naked Hungarian Man (Woman)']. Tiszatáj 5. 87-88.

Séllei, Nóra. 2007. "Hallgass a neve? Avagy hátborzongató elszólások" ['Not to be Heard? Or, Uncanny Slips of the Tongue']. Miért félünk a farkastól? Feminista irodalomszemlélet itt és most ['Why Afraid of the Wolf? Feminist Approaches to Literature Here and Now']. Debrecen: Debreceni Egyetemi Kiadó: 113-139.

Slethaug, Gordon E. 1993. "Parody." Encyclopedia of Contemporary Literary Theory. Approaches, Scholars, Terms. Ed. Irena R. Makaryk. Toronto: U of Toronto P: 603-605.

Szirák, Péter. 1998. Folytonosság és változás. A nyolcvanas évek magyar elbeszélő prózája ['Continuity and Change. On Hungarian Narrative Fiction of the Eighties']. Debrecen: Alföld Könyvek. 